\title{
Factors Contributing to the Use of L1 in English Classrooms: Listening to the Voice of Teachers and Students in Iranian Institutes
}

\author{
Mostafa Tajgozari
}

Shiraz University, Shiraz, Iran

E-mail: s.mtajgozari@rose.shirazu.ac.ir

Received: March 27, $2017 \quad$ Accepted: May 14, $2017 \quad$ Online Published: June 20, 2017

\begin{abstract}
By the growing emphasis on communicative language skills, the attention toward using first language in second language classrooms has been raised. The primary aim of this study was to find out teachers' and students' perceptions toward the utilization of L1 in English classrooms in Institutes. In order to do this objective, the researcher used a mixed methods research design. Two groups of participants were used in this study. They were 56 EFL learners of elementary, intermediate, and advanced level and 11 EFL teachers who were selected through convenient sampling. The proficiency level of the students was determined using Nelson Proficiency Test (NPT). The quantitative data were collected through a questionnaire while the qualitative data were collected through teachers' interviews. After the data collection and analysis, the results of this study revealed that students in all language levels in Institutes had positive perceptions toward utilizing L1 in L2 classes, teachers indicated their eagerness toward using L1 in their classes, and used L1 in high schools more than in Institutes. Furthermore, this study has some implications for EFL teachers.
\end{abstract}

Keywords: First Language (L1), Second Language (L2), students’ perceptions, teachers’ perceptions

\section{Introduction}

Last decades have witnessed different methodological shifts in English Language Teaching (ELT) and created a topic of debate regarding the use of L1 and learners' mother tongue in English as a Foreign Language (EFL) classes. Widely used in European and foreign language teaching, Grammar Translation Method (GTM) was popular from the 1840s to the 1940s and student's mother tongue (L1) was the medium of instruction (Richards \& Rodgers, 2003).

With the rise of direct method as an alternative to GTM around the 1900s, teachers stopped using L1 as the medium of instruction. Meanwhile, in the 19th century, a new approach was resulted with the emphasis on the spoken rather than written language, monolingual approach spreading its domination on language teaching. Some approaches like the behavioristic ones asserted that teachers must use L 2 or target language and the use of L1 should be banned at all costs in order to convey the information to students and improve the effectiveness of the instruction. It was believed that using L1 in L2 classes is one of the reasons that stops the appropriate second language learning and leads to some serious problems in the process of learners' second language learning (Richards \& Rodgers, 2003).

Many L2 teaching materials, syllabus, and curriculum reflect the learners L1 avoidance (Atkinson, 1987, 1993; G. Cook, 2002; V. Cook, 2001). Researchers believe that exposing to a wide range of input in target language is important for students to acquire L2 successfully. It can be stated that simulating an L2 environment is being considered a prerequisite of successful language leaning and effective language teaching (Asher, 1993; Chaudron, 1988; Ellis, 1984; Halliwell \& Jones, 1991; Krashen et al., 1984; Macdonald; 1993; Wong- Fillmore, 1985).

The use of L1 in L2 classes could cause some problems. Fear of excessive dependence is one of these commonest problems of L1 use (Atkinson, 1987; Cole, 1998). Atkinson (1987) explained that although they are completely capable of speaking and expressing their mind in L2, students interact with their teacher by using their L1 as a common feature of the course. The complete deletion of L1 from L2 classes is argued by some language experts (LarsenFreeman, 2000; Nation, 2003). Scholars have reiterated that teachers should use L1 cautiously and it should be wellplanned to yield positive results (Cook, 2001) and believed that if we tend to promote language learning and make it 


\section{International Journal of Research in English Education}

efficient, L1 use should not be neglected, as Cook (2001, p. 402) asserted, "open a door that has been firmly shut in language teaching for over 100 years."

The current research highlights that L1 has a role in the second or foreign language classroom (Atkinson, 1993; Cook, 2001; Garcia, 2009; Kumaravadivelu, 2006; Macaro, 1997). Many researchers asserted that the role of the mother tongue (L1) in the second and foreign language classroom is facilitating and cannot be neglected anymore (Cook, 2010; Kavaliauskienë \& Kaminskienë, 2007; Liao, 2006). Wells (1999) explained that new perspectives from Vygotsky's Sociocultural Theory (SCT) towards learning shed new lights to the potential role of the first language (L1) by providing a powerful explanatory framework for conceptualizing what is involved in language learning.

According to Yaghubi and Pouromid (2008), studies regarding the use of mother tongue in class by teachers and learners can be divided into three broad categories: First, studies which have attempted to recognize the functions of L1 use by learners (Anton \& DiCamilla, 1999; Scott \& De la Fuente, 2008; Stosch \& Wigglesworth, 2003; Swain \& Lapkin, 2000). Second, studies which have identified functions of L1 used by teachers (Copland \& Neokleous, 2010), and finally studies which are about attitudes of teachers and learners towards L1 use (Levine, 2003).

There are numerous studies which have investigated the teachers and learners' attitudes toward the role of L1 in L2 classes, specifically in Iranian context. But little attention has been paid to learners' and teachers' perspectives in Institutes. So, the need for further research and investigation with this regard has been felt. Therefore, the present study was designed in order to shed more lights on this controversy in the Iranian context by investigating EFL Learners' and teachers' perceptions on the use of L1 in English classrooms.

\section{Literature Review}

According to Brown (2000), the debate over whether learners' mother tongue should be used in English classrooms or not has been a contentious question for years, but the findings of researchers toward this issue have not been entirely persuasive. A brief look at the history of using L1 in the L2 classrooms reveals periodic changes in how it is viewed (Auerbach, 1993). The rise of an English-only classroom for political and practical reasons conversely brought about the exclusion of the student's L1. Those caught using L1 were often punished or shamed for doing something wrong (Phillipson, 1992). Pennycook (1994) asserted that the idea of using L1 in L2 classrooms was seen as unnatural. This belief that the native speakers are the best models and ideal teachers were the result of the emphasis on monolingual teaching of English. This was closely tied to political agendas, as well as the economics of the global EFL field (Pennycook, 1994). English speakers could control all the employment opportunities, by being seen as the 'ideal teacher.' The Makere (1961) emphasized the use of English in the classrooms and summarized his findings into five basic tenets which are as follows:

1. That English should be taught in a monolingual classroom.

2. The ideal teacher should be a native English speaker.

3. The earlier English is taught the better.

4. The more English used in the classroom during lessons, the better.

5. If other languages are used, English standards will drop (Phillipson, 1992).

Proponents of English-only also claim that using L1 in the classroom is not in accordance with SLA theories, which advocate modified input and negotiation in L2 as a means of learning (Polio, 1994). Negotiations of meaning and trial and error often lead to what has been dubbed an 'interlanguage', where a mix of L1 and L2 is used to communicate and establish the correct way of communicating in the L2 (Weschler, 1997). In recent views toward using L1 in L2 classrooms, some scholars and teachers have begun to advocate a more bilingual approach to teaching. This support has even gone as far as saying the use of L1 in the classroom is necessary (Schweers, 1999). As Zhou (2003) explained, countries like China have been successfully experimenting with bilingual English classes.

The use of learners' mother tongue in certain situation by both learners and teachers increases comprehension as well as learning of L2 (Atkinson, 1993; Cook, 2001; Kharma \& Hajjaj, 1989; Machaal, 2012; Tang, 2002; Wells, 1999). Several researchers reported the amount of L1 use and different functions for the use of L1 in pair/group work activities (Anton \& DiCamilla, 1999; Storch \& Aldosari, 2010; Storch \& Wiggleworth, 2003; Swain \& Lapkin, 2000). For example, Storch and Wigglesworth (2003) reported that mother tongue can have a number of functions, like enlisting 


\section{International Journal of Research in English Education}

and maintaining interest in the task as well as developing strategies to make a difficult task more manageable. But Jadallah and Hasan (2011) said that L1 should be used in a purposive manner, at appropriate times, and in appropriate places. Kharma and Hajjaj (1989) reported that the use of first language should not be over-emphasized and that it should decrease with the increase of the learners' experience with the second language.

The use of L1 serves a number of purposes such as to give instruction especially at the beginning levels in order to ensure that everyone fully understands what to do (Atkinson, 1987; Cole, 1998; Machaal, 2012; Tang, 2002), explain the meanings of words (Jingxia 2010; Morahan 2010; Tang 2002), explain complex ideas, translate from L1 to L2 when students do not have English words (Nadzrah Abu Bakar \& Kemboja Ismail 2009), and explain complex grammar points (Tang, 2002). With regard to students' perceptions about using L1 in L2 classes, Al Sharaeai (2014) looked into the reasons and perceptions learners have concerning using their mother tongue in L2 classrooms. It analyzes their opinions on different issues connected to first language use. The analysis for this paper was conducted on data from an online survey and follow-up interviews based on 51 total participants. The findings indicated that students used their first language for a variety of reasons. The amount of first language used also differed. The results showed that patterns emerged when considering the participants' language backgrounds, age, and the English language proficiency level.

Blooth, Azman, and Ismail (2014) investigated the use of L1 in the EFL reading classroom in a University in Yemen. A mixed method design was employed and data were collected from a sample of 45-Yemeni students studying English as a Foreign Language at the university. A questionnaire and semi-structured interviews were used for gathering data. The findings reveal that the students perceive the use of Arabic (L1) as functional strategy in their EFL (L2) classrooms and that it is used to serve a number of purposes: to translate new words, to define concepts, to give some explanations and to help each other in their groups. They concluded that L1 can be used as a scaffolding strategy by students in facilitating their learning and can be used as a pedagogical tool by the teacher to enhance learning experience as well as maximize engagement in the classroom.

Miles (2004) attempted to demonstrate two points. Firstly, using L1 in the classroom does not hinder learning and secondly L1 has a facilitating role to play in the classroom and can actually help learning. Two experiments were carried out in an attempt to substantiate these theories. In the first, three classes were observed over a period of five months, during which time one class was English-only, one permitted the use of Japanese by the students only, and in the other, both teacher and students utilized Japanese. In the second experiment, four separate lessons given to one class are compared (two where Japanese was used, and two where it was not permitted). Overall findings indicated possible support for both theories and thereby for the use of L1 in the classroom.

A lot of studies examined the students' and teachers' perceptions toward the issue. In his study of ESL trainee teachers as second language learners learning in the country where the language was spoken, Birch (1992) found that the teachers had a strong desire for their first language to be used in class. The findings of Birch's study suggest that inclusion of L1 is a learner-preferred strategy even when the learner is a teacher whose training and prior beliefs have led him or her to advocate an English-only approach. Another similar study was carried out on teachers' code switching to the L1 in EFL classes in three Chinese universities by Jingxia (2010). The data collection was based on qualitative and quantitative research method consisting of two questionnaires and classroom recordings. The results showed that code switching to Chinese exists in the EFL classes of Chinese universities. Moreover, most teachers (80\%) hold a positive view on teachers' code switching to the L1.

Afzal (2013) conducted a research on using L1 in EFL as a way of scaffolding for both students and teachers to learn and teach English. Based on the findings of this study, the majority of teachers used L1 in L2 classes. Although the main reasons for the use of L1 were the translation of some words, complex ideas or even whole passage, the study revealed that in the EFL classes Persian plays a supportive and facilitating role.

Rabani, Bejarzehi, and Ehsanjou (2014) investigated the perceptions of Iranian high school English teachers toward employing L1 (Persian) in teaching reading comprehension texts. The participants of the study were 30 Iranian high school teachers and the data were collected through questionnaires. The results revealed that the teachers had a positive view toward the use of Persian in teaching L2 reading texts. They believed that L1 can be used in teaching reading texts for several reasons, including the effects of L1 on enhancing learners' English skills and classroom interaction 


\section{International Journal of Research in English Education}

and also its effects on learners' affective and metacognitive aspects which increase the learner's comprehension in L2 reading texts.

Dujimoric (2014) carried out a research in the Croatian context. The data were collected through questionnaires. The results indicated that the translation of some words, complex ideas, or even the whole passage is a good way to learn a foreign language. The teachers believed that Croatian can be used to make the comprehension check and to make sure students have understood the text. He asserted that in the EFL classes, Croatian plays a supportive and facilitating role. Zohrabi, Yaghoubi-Notash, and khodadadi (2014) investigated the facilitating role of Iranian English foreign language learners' first language in learning of English vocabulary in Azarbayejan. This study used a mixed methods research design. There were 80 participants in the study including 50 EFL learners and 30 EFL teachers. According to the obtained results, most of the Azerbaijani-Turkish intermediate-level ELF learners had positive views towards the use of Turkish in learning English vocabulary and also Azerbaijani-Turkish ELF teachers had positive views towards the use of Turkish in learning English vocabulary.

Nazari (2008) investigated the Iranian university learners' perceptions toward the use of their mother tongue. A wellknown survey - Prodromou (2002) was employed and the findings were contradictory to the all previous similar studies. Iranian university learners reported reluctance to use their mother tongue. In line with Nazari (2008), Mahmoudi and Yazdi Amirkhiz (2011) conducted a study to observe classroom dynamics in terms of the quantity of use of L1 in two randomly-selected pre-university English classes in Ahvaz, Iran. The objective was to seek both students' and teachers' perceptions and attitudes towards the use of L1 in L2 classes. The classes were observed and video-taped for 6 sessions and the teachers and four high-achieving/low-achieving students were interviewed. The results indicated that an excessive use of Persian could have a de-motivating effect on students. Hence, the interviewed students voiced dissatisfaction with the untimely use and domination of L1 in L2 classes.

Larbah and Oliver (2015) investigated adult Arabic students' use of code switching (CS) in four university classrooms in Western Australia. An analysis of the data found that the use of CS was present in second language classrooms. Regardless of Arabic students' proficiency level, CS fulfils important functions. Overall, access to the L1 through CS assisted the learners to develop linguistic competence in the TL and worked to benefit their language learning. Thus, it is important that teachers understand that switching between L1 and the TL can enhance language acquisition. Debreli and Oyman (2016) conducted a study to investigate whether learners' educational background and their L2 proficiency affect their perceptions toward the use of Turkish in their L2 classrooms as well as their perceptions and needs for the use of L1 in their classrooms. The study was conducted on a sample of 303 Turkish learners of EFL at English Preparatory School of European University of Lefke in Northern Cyprus. Data were collected using a questionnaire. The results showed that EFL learners had high positive perceptions toward the inclusion of L1 in their L2 classes and that their perceptions were affected by their demographic characteristics. Students with lower level of L2 proficiency were found to have more positive perceptions toward the use of L1.

Although many studies have been carried out concerning using L1 in L2 classrooms all over the world and specially in Iranian context, the need for a comprehensive research toward the issue in Iranian Institutes' context was felt. Therefore, the present study tried to investigate EFL Learners' and teachers' perception on the use of L1 in English classrooms in Iranian Institutes by answering the following questions:

1- What are the Iranian students' perceptions toward using L1 in their English classes in institutes?

2- Do students with different levels of proficiency have different perceptions toward the importance of L1?

3- What are the Iranian EFL instructors' perceptions toward the effectiveness of using L1 and L2 in Institutes' English classes?

4- Is there any difference between using L1 in high schools English classes and English classes in Institutes?

5- What is the difference between teachers' and students' perceptions toward using L1 in L2 classes?

\section{Method}

\subsection{Participants}

Teachers and students were the survey groups in this study to figure out their perceptions toward using L1 in L2 classes. For this purpose, 56 male and female students in three different Institutes were selected using Nelson 


\section{International Journal of Research in English Education}

Proficiency Test (NPT) based on the results of their performance and divided into elementary, intermediate, and advanced level. The type of sampling for the selection of students and their classes was "convenience sampling" (Dornyei, 2007, p. 98). They were between 14 - 18 years old attending English Institutes in different levels in Darab, Iran and were native speakers of Farsi, the official language of Iran. Twenty of them were elementary, 18 were intermediate, and 18 of them were advanced based on the results of their scores in the placement test which was an Institute-made test. The variety of proficiency levels also will help to examine the relationship between students' proficiency levels and their attitudes toward the use of L1. All of the participants were high school students in different majors that attended English classes in Institutes. Their English classes were held three times per week in each semester.

In the other part of the study, 11 English language instructors were selected through convenient sampling. They were all graduated in TEFL and were between 22 and 39 years old from two Institutes in Darab. They had more than 6 years of English teaching experience. Students were given questionnaires to fill out while teachers were interviewed.

\subsection{Instruments}

First of all, in order to determine the proficiency level of the population and have a uniform data, a 50-item Nelson English Language Proficiency Test (section 350 A) by Fowler and Coe (1976) was used. This test is of a multiple choice which includes cloze passages, vocabulary, structure, and pronunciation items. The validity and reliability of the Nelson test have been estimated several times before by other researchers and it is considered as highly valid and reliable test of English proficiency (Shahivand \& Pazhakh, 2012, p. 18).

This study was of a mixed-method by using both qualitative and quantitative approach. For the purpose of this study, two methods were employed to collect the relevant data. The first method was the distribution of the questionnaires. A questionnaire taken from a related previous study (Prodromou, 2002) was used for the exploration of English learners' perceptions on the use of L1 in English classrooms. This questionnaire had two parts: Part I includes demographic information such as name, family name, age, and proficiency levels of students. Part II includes 16 items on a Likert scale to define student's attitudes. The reliability and validity of the questionnaire have been estimated by other researchers and it is considered as highly valid and reliable questionnaire. The researcher familiarity with the context of the study led to the assumption that Iranian high school students were not proficient enough to be able to understand English sentences perfectly well which raised doubts about the use of an English questionnaire and made him translate it into the students' mother tongue (Persian). Moreover, after translating it into Persian, the researcher asked one of his colleagues who was a native speaker of Persian and proficient enough in English to back-translate it into English in order for him to ensure the validity of the translated version. The second technique was to conduct semi-structured interview with all the participants from the teachers' group. The purpose of this was to find the reasons why they had to switch to mother-tongue (L1) and preferred using it over English.

\subsection{Data Collection and Analysis Procedures}

The researcher administered the questionnaire to 56 male and female students from different levels of English language proficiency studying at three different institutes. They were elementary, intermediate, and advanced between $14-18$ years old. After giving a short introduction to the project and identifying its advantages both for classroom teachers and students, students were asked to read the items and then decide to state whether they agree or disagree with the mentioned statements. All participants' questionnaires were divided into three parts, according to their levels of language proficiency (elementary, intermediate, and advanced). Each group's data were analyzed and the frequencies of agreement and disagreement marks were calculated. The obtained frequencies of all items were converted to percentages to determine which group of students agreed and disagreed on the use of their first language in their L2 classes. The researcher was present in the session to answer any probable questions they might have had and remove any ambiguities concerning the items of the questionnaire. The analysis of the data for the current study was done in SPSS 21 software utilizing descriptive statistics.

\section{Results and Discussion}

\subsection{Data Analysis of the Learners' Attitudes}

In order to answer the first question, the overall percentages of students' answers to the questionnaire items are provided in Table1. According to the results, students agree to use their mother tongue in English classes in Institutes. 


\section{International Journal of Research in English Education}

As Table1 shows, $90 \%$ of elementary students have positive perception toward using L1 in class in Institutes and just $26.7 \%$ of intermediate students are reluctant to do so. Also, 52.1\% of students in advanced level are eager to use L1 in class.

Table1. Percentage of students' positive and negative perception toward using L1 in class

\begin{tabular}{lccc}
\hline & Elementary & Intermediate & Advanced \\
\hline Agree & $90 \%$ & $73.3 \%$ & $52.1 \%$ \\
Disagree & $10 \%$ & $26.7 \%$ & $47.9 \%$ \\
\hline
\end{tabular}

In item $1,90 \%$ of elementary students believe that the teacher should use L1 in class in Institute while the percentages for intermediate and advanced level are $72 \%$ and $56 \%$ respectively which shows advanced level students are less eager than elementary and intermediate ones with regard to using L1 by teacher. With regard to Item 2, 100\% of students in elementary level believe that the students should use their mother tongue in class. $78 \%$ of intermediate students and $72 \%$ of advanced one agree with this regard.

Items 3, 4, 5, and 6 are about explaining new words, grammar, differences between L1 and L2 grammar, differences in the use of L1 and L2 rules respectively which show that all of the elementary students agree with. Intermediate students have positive perception with this regard but they are not as eager as elementary students and advanced students are more reluctant than intermediate students. In Item 3, 67\% of advanced students believe that teachers should not explain new words in L1. 


\section{International Journal of Research in English Education}

Table 2. Frequencies and percentages of students' positive answers toward using L1 in classes

\begin{tabular}{cccc}
\hline & Elementary & Intermediate & Advanced \\
Questionnaire Items & N 20 & N 18 & N 18
\end{tabular}

Items

\begin{tabular}{|c|c|c|c|c|c|c|}
\hline & $\mathrm{f}$ & $\mathrm{p}$ & $\mathrm{f}$ & $\mathrm{p}$ & f & $\mathrm{p}$ \\
\hline 1. $\quad$ Should the teacher use the L1? & 18 & $90 \%$ & 13 & $72 \%$ & 10 & $56 \%$ \\
\hline
\end{tabular}

2. Should the students use their L1?

\begin{tabular}{|c|c|c|c|c|c|}
\hline \multirow[b]{2}{*}{$\mathrm{f}$} & $\begin{array}{c}\text { Elementary } \\
\text { N } 20\end{array}$ & \multicolumn{3}{|c|}{$\begin{array}{c}\text { Intermediate } \\
\text { N } 18\end{array}$} & \multirow{2}{*}{$\begin{array}{l}\text { Advanced } \\
\text { N } 18 \\
\text { p }\end{array}$} \\
\hline & $\mathrm{p}$ & $\mathrm{f}$ & $\mathrm{p}$ & $\mathrm{f}$ & \\
\hline 18 & $90 \%$ & 13 & $72 \%$ & 10 & $56 \%$ \\
\hline 20 & $100 \%$ & 14 & $78 \%$ & 13 & $72 \%$ \\
\hline 20 & $100 \%$ & 14 & $78 \%$ & 6 & $33 \%$ \\
\hline 20 & $100 \%$ & 16 & $89 \%$ & 14 & $78 \%$ \\
\hline 20 & $100 \%$ & 18 & $100 \%$ & 16 & $89 \%$ \\
\hline 20 & $100 \%$ & 18 & $100 \%$ & 16 & $89 \%$ \\
\hline 17 & $85 \%$ & 13 & $72 \%$ & 5 & $28 \%$ \\
\hline 16 & $80 \%$ & 11 & $61 \%$ & 3 & $17 \%$ \\
\hline 20 & $100 \%$ & 18 & $100 \%$ & 18 & $100 \%$ \\
\hline 15 & $75 \%$ & 12 & $67 \%$ & 6 & $33 \%$ \\
\hline 14 & $70 \%$ & 11 & $61 \%$ & 3 & $17 \%$ \\
\hline 20 & $100 \%$ & 12 & $67 \%$ & 8 & $44 \%$ \\
\hline
\end{tabular}

3. Explaining new words in L1

\begin{tabular}{|c|c|c|c|c|c|}
\hline \multirow[b]{2}{*}{$\mathrm{f}$} & $\begin{array}{c}\text { Elementary } \\
\text { N } 20\end{array}$ & \multicolumn{3}{|c|}{$\begin{array}{c}\text { Intermediate } \\
\text { N } 18\end{array}$} & \multirow{2}{*}{$\begin{array}{l}\text { Advanced } \\
\text { N } 18 \\
\text { p }\end{array}$} \\
\hline & $\mathrm{p}$ & $\mathrm{f}$ & $\mathrm{p}$ & $\mathrm{f}$ & \\
\hline 18 & $90 \%$ & 13 & $72 \%$ & 10 & $56 \%$ \\
\hline 20 & $100 \%$ & 14 & $78 \%$ & 13 & $72 \%$ \\
\hline 20 & $100 \%$ & 14 & $78 \%$ & 6 & $33 \%$ \\
\hline 20 & $100 \%$ & 16 & $89 \%$ & 14 & $78 \%$ \\
\hline 20 & $100 \%$ & 18 & $100 \%$ & 16 & $89 \%$ \\
\hline 20 & $100 \%$ & 18 & $100 \%$ & 16 & $89 \%$ \\
\hline 17 & $85 \%$ & 13 & $72 \%$ & 5 & $28 \%$ \\
\hline 16 & $80 \%$ & 11 & $61 \%$ & 3 & $17 \%$ \\
\hline 20 & $100 \%$ & 18 & $100 \%$ & 18 & $100 \%$ \\
\hline 15 & $75 \%$ & 12 & $67 \%$ & 6 & $33 \%$ \\
\hline 14 & $70 \%$ & 11 & $61 \%$ & 3 & $17 \%$ \\
\hline 20 & $100 \%$ & 12 & $67 \%$ & 8 & $44 \%$ \\
\hline
\end{tabular}

4. Explaining grammar in L1

\begin{tabular}{|c|c|c|c|c|c|}
\hline \multirow[b]{2}{*}{$\mathrm{f}$} & $\begin{array}{l}\text { Elementary } \\
\text { N } 20\end{array}$ & \multicolumn{3}{|c|}{$\begin{array}{l}\text { Intermediate } \\
\text { N } 18\end{array}$} & \multirow{2}{*}{$\begin{array}{c}\text { Advanced } \\
\text { N } 18 \\
\text { p }\end{array}$} \\
\hline & $\mathrm{p}$ & $\mathrm{f}$ & $\mathrm{p}$ & $\mathrm{f}$ & \\
\hline 18 & $90 \%$ & 13 & $72 \%$ & 10 & $56 \%$ \\
\hline 20 & $100 \%$ & 14 & $78 \%$ & 13 & $72 \%$ \\
\hline 20 & $100 \%$ & 14 & $78 \%$ & 6 & $33 \%$ \\
\hline 20 & $100 \%$ & 16 & $89 \%$ & 14 & $78 \%$ \\
\hline 20 & $100 \%$ & 18 & $100 \%$ & 16 & $89 \%$ \\
\hline 20 & $100 \%$ & 18 & $100 \%$ & 16 & $89 \%$ \\
\hline 17 & $85 \%$ & 13 & $72 \%$ & 5 & $28 \%$ \\
\hline 16 & $80 \%$ & 11 & $61 \%$ & 3 & $17 \%$ \\
\hline 20 & $100 \%$ & 18 & $100 \%$ & 18 & $100 \%$ \\
\hline 15 & $75 \%$ & 12 & $67 \%$ & 6 & $33 \%$ \\
\hline 14 & $70 \%$ & 11 & $61 \%$ & 3 & $17 \%$ \\
\hline 20 & $100 \%$ & 12 & $67 \%$ & 8 & $44 \%$ \\
\hline
\end{tabular}

5. Explaining differences between L1 \&

\begin{tabular}{|c|c|c|c|c|c|}
\hline \multirow[b]{2}{*}{$\mathrm{f}$} & $\begin{array}{c}\text { Elementary } \\
\text { N } 20\end{array}$ & \multicolumn{3}{|c|}{$\begin{array}{c}\text { Intermediate } \\
\text { N } 18\end{array}$} & \multirow{2}{*}{$\begin{array}{l}\text { Advanced } \\
\text { N } 18 \\
\text { p }\end{array}$} \\
\hline & $\mathrm{p}$ & $\mathrm{f}$ & $\mathrm{p}$ & $\mathrm{f}$ & \\
\hline 18 & $90 \%$ & 13 & $72 \%$ & 10 & $56 \%$ \\
\hline 20 & $100 \%$ & 14 & $78 \%$ & 13 & $72 \%$ \\
\hline 20 & $100 \%$ & 14 & $78 \%$ & 6 & $33 \%$ \\
\hline 20 & $100 \%$ & 16 & $89 \%$ & 14 & $78 \%$ \\
\hline 20 & $100 \%$ & 18 & $100 \%$ & 16 & $89 \%$ \\
\hline 20 & $100 \%$ & 18 & $100 \%$ & 16 & $89 \%$ \\
\hline 17 & $85 \%$ & 13 & $72 \%$ & 5 & $28 \%$ \\
\hline 16 & $80 \%$ & 11 & $61 \%$ & 3 & $17 \%$ \\
\hline 20 & $100 \%$ & 18 & $100 \%$ & 18 & $100 \%$ \\
\hline 15 & $75 \%$ & 12 & $67 \%$ & 6 & $33 \%$ \\
\hline 14 & $70 \%$ & 11 & $61 \%$ & 3 & $17 \%$ \\
\hline 20 & $100 \%$ & 12 & $67 \%$ & 8 & $44 \%$ \\
\hline
\end{tabular}

\begin{tabular}{|c|c|c|c|c|c|}
\hline \multirow[b]{2}{*}{$\mathrm{f}$} & $\begin{array}{c}\text { Elementary } \\
\text { N } 20\end{array}$ & \multicolumn{3}{|c|}{$\begin{array}{l}\text { Intermediate } \\
\text { N } 18\end{array}$} & \multirow{2}{*}{$\begin{array}{l}\text { Advanced } \\
\text { N } 18 \\
\text { p }\end{array}$} \\
\hline & $\mathrm{p}$ & $\mathrm{f}$ & $\mathrm{p}$ & $\mathrm{f}$ & \\
\hline 18 & $90 \%$ & 13 & $72 \%$ & 10 & $56 \%$ \\
\hline 20 & $100 \%$ & 14 & $78 \%$ & 13 & $72 \%$ \\
\hline 20 & $100 \%$ & 14 & $78 \%$ & 6 & $33 \%$ \\
\hline 20 & $100 \%$ & 16 & $89 \%$ & 14 & $78 \%$ \\
\hline 20 & $100 \%$ & 18 & $100 \%$ & 16 & $89 \%$ \\
\hline 20 & $100 \%$ & 18 & $100 \%$ & 16 & $89 \%$ \\
\hline 17 & $85 \%$ & 13 & $72 \%$ & 5 & $28 \%$ \\
\hline 16 & $80 \%$ & 11 & $61 \%$ & 3 & $17 \%$ \\
\hline 20 & $100 \%$ & 18 & $100 \%$ & 18 & $100 \%$ \\
\hline 15 & $75 \%$ & 12 & $67 \%$ & 6 & $33 \%$ \\
\hline 14 & $70 \%$ & 11 & $61 \%$ & 3 & $17 \%$ \\
\hline 20 & $100 \%$ & 12 & $67 \%$ & 8 & $44 \%$ \\
\hline
\end{tabular}

\section{L2}

6. Explaining differences in the use of L1

\begin{tabular}{|c|c|c|c|c|c|}
\hline \multirow[b]{2}{*}{$\mathrm{f}$} & $\begin{array}{l}\text { Elementary } \\
\text { N } 20\end{array}$ & \multicolumn{3}{|c|}{$\begin{array}{l}\text { Intermediate } \\
\text { N } 18\end{array}$} & \multirow{2}{*}{$\begin{array}{l}\text { Advanced } \\
\text { N } 18 \\
\text { p }\end{array}$} \\
\hline & $\mathrm{p}$ & $\mathrm{f}$ & $\mathrm{p}$ & $\mathrm{f}$ & \\
\hline 18 & $90 \%$ & 13 & $72 \%$ & 10 & $56 \%$ \\
\hline 20 & $100 \%$ & 14 & $78 \%$ & 13 & $72 \%$ \\
\hline 20 & $100 \%$ & 14 & $78 \%$ & 6 & $33 \%$ \\
\hline 20 & $100 \%$ & 16 & $89 \%$ & 14 & $78 \%$ \\
\hline 20 & $100 \%$ & 18 & $100 \%$ & 16 & $89 \%$ \\
\hline 20 & $100 \%$ & 18 & $100 \%$ & 16 & $89 \%$ \\
\hline 17 & $85 \%$ & 13 & $72 \%$ & 5 & $28 \%$ \\
\hline 16 & $80 \%$ & 11 & $61 \%$ & 3 & $17 \%$ \\
\hline 20 & $100 \%$ & 18 & $100 \%$ & 18 & $100 \%$ \\
\hline 15 & $75 \%$ & 12 & $67 \%$ & 6 & $33 \%$ \\
\hline 14 & $70 \%$ & 11 & $61 \%$ & 3 & $17 \%$ \\
\hline 20 & $100 \%$ & 12 & $67 \%$ & 8 & $44 \%$ \\
\hline
\end{tabular}

$100 \% \quad 18 \quad 100 \% \quad 16$

$89 \%$ \& L2

7. Giving instructions in L1

\begin{tabular}{|c|c|c|c|c|c|}
\hline \multirow[b]{2}{*}{$\mathrm{f}$} & $\begin{array}{l}\text { Elementary } \\
\text { N } 20\end{array}$ & \multicolumn{3}{|c|}{$\begin{array}{l}\text { Intermediate } \\
\text { N } 18\end{array}$} & \multirow{2}{*}{$\begin{array}{l}\text { Advanced } \\
\text { N } 18 \\
\text { p }\end{array}$} \\
\hline & $\mathrm{p}$ & $\mathrm{f}$ & $\mathrm{p}$ & $\mathrm{f}$ & \\
\hline 18 & $90 \%$ & 13 & $72 \%$ & 10 & $56 \%$ \\
\hline 20 & $100 \%$ & 14 & $78 \%$ & 13 & $72 \%$ \\
\hline 20 & $100 \%$ & 14 & $78 \%$ & 6 & $33 \%$ \\
\hline 20 & $100 \%$ & 16 & $89 \%$ & 14 & $78 \%$ \\
\hline 20 & $100 \%$ & 18 & $100 \%$ & 16 & $89 \%$ \\
\hline 20 & $100 \%$ & 18 & $100 \%$ & 16 & $89 \%$ \\
\hline 17 & $85 \%$ & 13 & $72 \%$ & 5 & $28 \%$ \\
\hline 16 & $80 \%$ & 11 & $61 \%$ & 3 & $17 \%$ \\
\hline 20 & $100 \%$ & 18 & $100 \%$ & 18 & $100 \%$ \\
\hline 15 & $75 \%$ & 12 & $67 \%$ & 6 & $33 \%$ \\
\hline 14 & $70 \%$ & 11 & $61 \%$ & 3 & $17 \%$ \\
\hline 20 & $100 \%$ & 12 & $67 \%$ & 8 & $44 \%$ \\
\hline
\end{tabular}

8. Talking in pairs and groups in L1

\begin{tabular}{|c|c|c|c|c|c|}
\hline \multirow[b]{2}{*}{$\mathrm{f}$} & $\begin{array}{l}\text { Elementary } \\
\text { N } 20\end{array}$ & \multicolumn{3}{|c|}{$\begin{array}{l}\text { Intermediate } \\
\text { N } 18\end{array}$} & \multirow{2}{*}{$\begin{array}{l}\text { Advanced } \\
\text { N } 18 \\
\text { p }\end{array}$} \\
\hline & $\mathrm{p}$ & $\mathrm{f}$ & $\mathrm{p}$ & $\mathrm{f}$ & \\
\hline 18 & $90 \%$ & 13 & $72 \%$ & 10 & $56 \%$ \\
\hline 20 & $100 \%$ & 14 & $78 \%$ & 13 & $72 \%$ \\
\hline 20 & $100 \%$ & 14 & $78 \%$ & 6 & $33 \%$ \\
\hline 20 & $100 \%$ & 16 & $89 \%$ & 14 & $78 \%$ \\
\hline 20 & $100 \%$ & 18 & $100 \%$ & 16 & $89 \%$ \\
\hline 20 & $100 \%$ & 18 & $100 \%$ & 16 & $89 \%$ \\
\hline 17 & $85 \%$ & 13 & $72 \%$ & 5 & $28 \%$ \\
\hline 16 & $80 \%$ & 11 & $61 \%$ & 3 & $17 \%$ \\
\hline 20 & $100 \%$ & 18 & $100 \%$ & 18 & $100 \%$ \\
\hline 15 & $75 \%$ & 12 & $67 \%$ & 6 & $33 \%$ \\
\hline 14 & $70 \%$ & 11 & $61 \%$ & 3 & $17 \%$ \\
\hline 20 & $100 \%$ & 12 & $67 \%$ & 8 & $44 \%$ \\
\hline
\end{tabular}

9. Asking in L1 how do we say “...” in

\begin{tabular}{|c|c|c|c|c|c|}
\hline \multirow[b]{2}{*}{$\mathrm{f}$} & $\begin{array}{l}\text { Elementary } \\
\text { N } 20\end{array}$ & \multicolumn{3}{|c|}{$\begin{array}{l}\text { Intermediate } \\
\text { N } 18\end{array}$} & \multirow{2}{*}{$\begin{array}{c}\text { Advanced } \\
\text { N } 18 \\
\text { p }\end{array}$} \\
\hline & $\mathrm{p}$ & $\mathrm{f}$ & $\mathrm{p}$ & $\mathrm{f}$ & \\
\hline 18 & $90 \%$ & 13 & $72 \%$ & 10 & $56 \%$ \\
\hline 20 & $100 \%$ & 14 & $78 \%$ & 13 & $72 \%$ \\
\hline 20 & $100 \%$ & 14 & $78 \%$ & 6 & $33 \%$ \\
\hline 20 & $100 \%$ & 16 & $89 \%$ & 14 & $78 \%$ \\
\hline 20 & $100 \%$ & 18 & $100 \%$ & 16 & $89 \%$ \\
\hline 20 & $100 \%$ & 18 & $100 \%$ & 16 & $89 \%$ \\
\hline 17 & $85 \%$ & 13 & $72 \%$ & 5 & $28 \%$ \\
\hline 16 & $80 \%$ & 11 & $61 \%$ & 3 & $17 \%$ \\
\hline 20 & $100 \%$ & 18 & $100 \%$ & 18 & $100 \%$ \\
\hline 15 & $75 \%$ & 12 & $67 \%$ & 6 & $33 \%$ \\
\hline 14 & $70 \%$ & 11 & $61 \%$ & 3 & $17 \%$ \\
\hline 20 & $100 \%$ & 12 & $67 \%$ & 8 & $44 \%$ \\
\hline
\end{tabular}

English?

10. Translating an L2 word into L1

\begin{tabular}{|c|c|c|c|c|c|}
\hline \multirow[b]{2}{*}{$\mathrm{f}$} & $\begin{array}{c}\text { Elementary } \\
\text { N } 20\end{array}$ & \multicolumn{3}{|c|}{$\begin{array}{l}\text { Intermediate } \\
\text { N } 18\end{array}$} & \multirow{2}{*}{$\begin{array}{l}\text { Advanced } \\
\text { N } 18 \\
\text { p }\end{array}$} \\
\hline & $\mathrm{p}$ & $\mathrm{f}$ & $\mathrm{p}$ & $\mathrm{f}$ & \\
\hline 18 & $90 \%$ & 13 & $72 \%$ & 10 & $56 \%$ \\
\hline 20 & $100 \%$ & 14 & $78 \%$ & 13 & $72 \%$ \\
\hline 20 & $100 \%$ & 14 & $78 \%$ & 6 & $33 \%$ \\
\hline 20 & $100 \%$ & 16 & $89 \%$ & 14 & $78 \%$ \\
\hline 20 & $100 \%$ & 18 & $100 \%$ & 16 & $89 \%$ \\
\hline 20 & $100 \%$ & 18 & $100 \%$ & 16 & $89 \%$ \\
\hline 17 & $85 \%$ & 13 & $72 \%$ & 5 & $28 \%$ \\
\hline 16 & $80 \%$ & 11 & $61 \%$ & 3 & $17 \%$ \\
\hline 20 & $100 \%$ & 18 & $100 \%$ & 18 & $100 \%$ \\
\hline 15 & $75 \%$ & 12 & $67 \%$ & 6 & $33 \%$ \\
\hline 14 & $70 \%$ & 11 & $61 \%$ & 3 & $17 \%$ \\
\hline 20 & $100 \%$ & 12 & $67 \%$ & 8 & $44 \%$ \\
\hline
\end{tabular}

11. Translating a text from L2 to L1

\begin{tabular}{|c|c|c|c|c|c|}
\hline \multirow[b]{2}{*}{$\mathrm{f}$} & $\begin{array}{l}\text { Elementary } \\
\text { N } 20\end{array}$ & \multicolumn{3}{|c|}{$\begin{array}{l}\text { Intermediate } \\
\text { N } 18\end{array}$} & \multirow{2}{*}{$\begin{array}{c}\text { Advanced } \\
\text { N } 18 \\
\text { p }\end{array}$} \\
\hline & $\mathrm{p}$ & $\mathrm{f}$ & $\mathrm{p}$ & $\mathrm{f}$ & \\
\hline 18 & $90 \%$ & 13 & $72 \%$ & 10 & $56 \%$ \\
\hline 20 & $100 \%$ & 14 & $78 \%$ & 13 & $72 \%$ \\
\hline 20 & $100 \%$ & 14 & $78 \%$ & 6 & $33 \%$ \\
\hline 20 & $100 \%$ & 16 & $89 \%$ & 14 & $78 \%$ \\
\hline 20 & $100 \%$ & 18 & $100 \%$ & 16 & $89 \%$ \\
\hline 20 & $100 \%$ & 18 & $100 \%$ & 16 & $89 \%$ \\
\hline 17 & $85 \%$ & 13 & $72 \%$ & 5 & $28 \%$ \\
\hline 16 & $80 \%$ & 11 & $61 \%$ & 3 & $17 \%$ \\
\hline 20 & $100 \%$ & 18 & $100 \%$ & 18 & $100 \%$ \\
\hline 15 & $75 \%$ & 12 & $67 \%$ & 6 & $33 \%$ \\
\hline 14 & $70 \%$ & 11 & $61 \%$ & 3 & $17 \%$ \\
\hline 20 & $100 \%$ & 12 & $67 \%$ & 8 & $44 \%$ \\
\hline
\end{tabular}

12. Using translation tasks in a test

13. Using L1 to check listening

$\begin{array}{llllll}20 & 100 \% & 12 & 67 \% & 8 & 44 \%\end{array}$

$$
\text { comprehension }
$$

14. Using L1 to check reading comprehension

15. Discussing in L1 the methods used in class

$\begin{array}{llllll}10 & 50 \% & 3 & 17 \% & 0 & 0 \%\end{array}$

$\begin{array}{llllll}18 & 90 \% & 7 & 39 \% & 2 & 11 \%\end{array}$

$\begin{array}{llllll}20 & 100 \% & 13 & 72 \% & 12 & 67 \%\end{array}$

Key: $f=$ frequency; $p=$ percentage 


\section{International Journal of Research in English Education}

Item 7 is about giving instructions by teacher in L1 which $85 \%$ and $72 \%$ of elementary and intermediate students agree with while, $28 \%$ of advanced students have positive attitude with this item.

In the next item, just $20 \%$ of elementary and $39 \%$ of intermediate students believe that learners should not use L1 while talking in pairs and groups. In contrast, students of advanced level have negative perceptions toward this item. Interestingly, all the students in all the levels had positive perceptions with regard to item 9. The next two items (Items 10 and 11) are about the translation of L2 words and texts to L1. Most of the elementary and intermediate students agree with the items while students of advanced level have negative perceptions toward the items. All the students in elementary level and $67 \%$ of intermediate students agree with using translation tasks in item 12, while $44 \%$ of advanced level students have positive view toward it.

Results show that students in all of the levels are reluctant with regard to the next item (item 13) which was about checking listening comprehension by teachers and students using L1 (elementary 50\%, intermediate 17\%, and advanced $0 \%$ ). $90 \%$ of elementary students agree with the next item which was about checking reading comprehension by teachers and students using L1 while the other two levels are reluctant about it and finally students show eagerness about discussing in L1 the methods used in class.

\subsection{Discussion of Learners' Attitudes}

As the results showed, English learners in Institutes have positive perception toward using L1 in their English classes. Based on the results, $90 \%$ of elementary students, $73.3 \%$ and $52.1 \%$ of intermediate and advanced students agree with using L1 in classes respectively. According to the results in Table 2, all of the students (elementary, intermediate, and advanced) believed that the teacher should know the students' mother tongue. Students have the same perception toward asking in L1 how do we say "..." in English. Although the advanced students had positive perception with regard to using L1 in class, they strongly disagree to use L1 to check listening comprehension, $0 \%$. They are also reluctant to use L1 to check reading comprehension (11\%) and translating a text from L2 to L1 (17\%).

The findings of the present study are in line with the study of Debreli and Oyman (2016) who investigated whether students' educational background and their L2 proficiency influenced their perceptions of the use of Turkish in their L2 classrooms as well as their perceptions and needs for the use of L1 in their classrooms. They concluded that EFL students had high positive perceptions toward the inclusion of L1 in their L2 classes and that their perceptions were affected by their demographic characteristics. Students with lower level of L2 proficiency were also found to have more positive perceptions toward the use of L1.

In another study which looked into the reasons and perspectives toward the use of L1 in L2 classes, Al Sharaeai (2014) concluded that students used their first language for a variety of reasons and the amount of first language use differed based on students English language proficiency level which is in line with the findings of the present study. Moreover, Blooth, Azman, and Ismail (2014) concluded that students perceive that the use of L1 in class is useful.

Afzal (2013) also concluded that students have positive attitude toward using L1 in class. The findings are also consistent with the results of Prodromou (2002) who concluded that translating from L2 to L1 is a useful way in learning the new language and using students' mother tongue enhances the interaction. On the other hand, Nazari (2008) reported that students are reluctant to use their L1, which is not consistent with the results of this study.

\subsection{Data Analysis of Teachers' Attitudes}

In order to answer the third and fourth research questions, the researcher conducted a semi structured interview with 11 English teachers in two different institutes. All of the participants preferred to be interviewed in English ( $N=11)$. These interview sessions were recorded and transcribed by the researcher. Next, the transcriptions were qualitatively analyzed by the researcher to find out the answer to the previously mentioned research question.

Responding to the first question, which was "Should English teachers use L1 in the L2 classrooms? Why? " most of the teachers ( $\mathrm{N}=8)$ said English teachers should not use L1 in L2 classes. For example, one of the teachers, teacher 1, said, "Not at all." Because the class is a place where students are exposed to target language and have the chance to hear English and learn it. So why should we miss this chance by using L1 in class? As another example, teacher 3 talked about students de-motivation to learn English. He said, "I think teachers should not use L1 in their classes because this may make students stop challenging to learn English and in consequence demotivates them to learn English. In contrast to teachers who believed that teachers shouldn't use L1, teacher 5 said, "instructors can use 


\section{International Journal of Research in English Education}

L1 when students are not active in the class and don't ask questions or not eager to participate in class discussions. So I think teacher should use L1 in L2 classes.

Regarding the second question which was "When do teachers can use L1 in class?" almost all the teachers (N=10) believed that L1 must be used judiciously and most of them believed that grammar points could be taught using L1. One of the surveyed teachers, teacher 6, said, "Teachers should be cautions with regard to use L1. For example, grammar can be taught using L1. Sometimes it is hard to understand grammar points when they are taught in target language." Teacher 9 pointed to another case when teachers can use L1: "Actually it's hard to decide when and where teachers can use L1 because it depends on many factors. But I think when it comes to cultural points, it's better to use L1 to elaborate on the points." In contrast to other teachers, just teacher 7 expressed: "when students don't learn, and you as a teacher can easily realize that teachers must shift to L1 to elaborate on the points and motivate students to learn."

As the third question, the researcher asked the interviewees, "Does using L1 build up a good relationship with students? Teachers' responses to this question showed their different attitudes toward using L1 to build up a good relationship with students. Four of them believed that it does. For example, teachers 10 and 3 pointed that by using L1, teachers can reduce students' stress so they learn better and the relationship with teachers would be without stress and fear. On the other hand, some other teachers $(\mathrm{N}=4)$ believed that using $\mathrm{L} 1$ does not lead to a friendly atmosphere between teachers and students. Teacher 4 believed that, "Sometimes, using L1 in the class indicates that the teacher doesn't have the power or the knowledge to control and manage the class."

Teachers 2, 11, and 5 believed that it depends on different factors. Teacher 5 said, "It depends. For example in a class where there is no participation from students, which is because of using L2, the teacher should shift to L1 to change the atmosphere and build a good relationship with students using their mother tongue. But, in a class of high level where students can easily understand and are active, it is better to stick to L2 and not to use L1 because the relationship is good and they are learning."

For the last question, the researcher asked the teachers, "Is there any difference between using L1 in high schools' English classes and English classes in Institutes?" All of the teachers ( $=11)$ pointed that teachers use L1 in high schools more than in Institutes. As an example, teacher 8 said, "In Institutes, teachers usually use L2 as the medium of instruction and there is no place for L1. Students are there to enhance their English level more than what they deal with in high schools." Another teacher, teacher 6, pointed that, "Actually, teachers use L1 in high schools more than in Institutes because Institutes are specific places where students pay to learn English beside what they learn in schools. So, teachers use L2 as the medium of instruction. I've seen a lot that teachers use L1 as the medium of instruction in high schools."

\subsection{Discussion of Teachers' Attitudes}

According to the teachers' responses, although some of them $(\mathrm{N}=4)$ believed that using $\mathrm{L} 1$ can build up a good relationship with students, most of them $(\mathrm{N}=8)$ expressed their unwillingness to use L1 in English classes. 10 of them believed that if teachers want to use L1, they should be cautions which shows using L1 can be a risky move and may decrease the learning and most of them said if teachers want to use L1, they can use it to explain grammar points. The result supports the finding of Mugla and Seedhouse (2005). They came up with the fact that teachers made use of first language when they wanted to explain the grammatical points. Asking about the difference between using L1 in high schools and Institutes, unanimously all the teachers believed that there is a difference in using L1 and English instructors use L1 in Institutes much less than they do in high schools.

Larbah and Oliver (2015) concluded that access to the L1 through code switching assisted the learners to develop linguistic competence in the target language and worked to benefit their language learning. Therefore, it is important that teachers understand that switching between L1 and L2 can enhance language acquisition. Ellis (2008) asserted that in foreign language contexts, learners' only source exposure to the L2 may be classroom so teachers should use target language in classroom.

As a similar study which was carried out on teachers' code switching to the L1 in EFL classes in three Chinese universities, Jingxia (2010) showed that code switching to Chinese exists in the EFL classes of Chinese universities. Moreover, most teachers $(80 \%)$ hold a positive view on teachers' code switching to the L1. The results are not in 


\section{International Journal of Research in English Education}

accordance with the findings of this study. Miles (2004) showed that firstly using L1 in the classroom does not hinder learning and secondly L1 has a facilitating role to play in the classroom and can actually help learning. As another example, Prodromou (2002) pointed that translation use is a helping way in learning the new language. In addition, mother tongue in the classroom enhances the quality of interaction and it won't be restricted or banned in the classroom language process.

\subsection{Comparing Teachers' and Students' Perceptions}

In order to answer the last research question about the difference between teachers' and students' perceptions, the researcher compared the results of them. As stated earlier, English learners in Institutes have positive perception toward using L1 in their English classes. Based on the results, $90 \%$ of elementary students, $73.3 \%$ and $52.1 \%$ of intermediate and advanced students agree with using L1 in classes respectively. But teachers' results showed an opposite view. They believed that teachers should use L2 as much as possible because English class is the only place where students can hear and speak English. So teachers and students have opposite views regarding using L1.

The findings of a study done by Hashemi and Khalili Sabet (2013) support the findings of the present study. Hashemi and Khalili Sabet (2013) examined the perception of Iranian EFL students and lecturers towards the effective use of L1 (Persian) and L2 (English) in General English (GE) classes at the university level. The analysis of the results indicated that the Iranian EFL students believe in the effectiveness of L1 use in GE classes. Meanwhile, this study showed that the Iranian EFL lecturers have a positive tendency to use more English than Persian in the GE classes.

In contrast, Zohrabi, Yaghoubi-Notash, and Khodadadi (2014) investigated the facilitating role of the Iranian English Foreign Language learners' first language in learning of English vocabulary in Azarbayejan and the results showed that most of the Azerbaijani-Turkish intermediate-level EFL learners had positive views towards the use of Turkish in learning English vocabulary, but Azerbaijani-Turkish EFL teachers had positive views towards the use of Turkish in learning English vocabulary.

\section{Conclusion}

This study aimed to determine teachers' and learners' attitudes toward the role of L1 in L2 classes in Institutes. Bases on the results obtained from teachers and students, it can be concluded that although English learners in Institutes have positive perception toward using L1 in their English classes, most of the surveyed teachers showed their unwillingness to use L1 in their classes. With regard to students' language proficiency, $90 \%$ of elementary students, $73.3 \%$ of intermediate, and 52.1\% of advanced students had positive perceptions toward using L1 in English classes. In addition, the findings showed that teachers use L1 in high schools more than in Institutes.

The findings can be applied to construct a better learning condition in language learning classes, not only in Institutes but also in schools. Teachers might suggest translation more for some learners than others, and help students raise their awareness about the merits and demerits of using translation. Furthermore, educators might encourage the learners' perspectives of translation as an effective and efficient strategy but to use it with caution.

This study suffers from limitations which have to be taken into consideration in next studies. The number of the teachers in this study was a small sample that cannot properly represent the whole population of EFL teachers. This study was also conducted in English Institutes and did not take into account public high schools or other contexts. Other studies can investigate teachers' and students' perceptions toward the issue, using L1 in L2 classes, in high schools or universities.

\section{References}

Afzal, S. (2013). Using of the First Language in English classroom as a way of scaffolding for both the students and teachers to learn and teach English. International Research Journal of Applied and Basic Sciences, 4(7), 18461854. Retrieved from: www.irjabs.com

Al Sharaeai, W. A. A. (2012). Students' perspectives on the use of L1 in English classrooms. Digital Repository @ Iowa State University. http://lib.dr.iastate.edu/cgi/viewcontent.cgi?article=3905\&context=etd

Anton, M., \& Dicamilla, F. J. (1999). Socio-cognitive functions of L1 collaborative interaction in the L2 classroom. The Modern Language Journal, 83(2), 233-247. 


\section{International Journal of Research in English Education}

Asher, C. (1993). Using the target language as the medium of instruction in the communicative classroom: The influence of practice on principle. Studies in Modern Languages Education, 1, 225-238. http://www.sciencedirect.com/science/article/pii/S1877042811028758\#bbib0005

Atkinson, D. (1987). The mother tongue in the classroom: a neglected resource? ELT Journal, 41(4), 241-247. http://www.tandfonline.com/doi/abs/10.1080/09571739385200261

Atkinson, D. (1993). Teaching in the target language: a problem in the current orthodoxy. Language Learning Journal, 8, 2-5. https://www.jstor.org/stable/3586949?seq=1\#page_scan_tab_contents

Auerbach, E. (1993). Reexamining English only in the ESL classroom. TESOL Quarterly, 27(1), 9-32. http://www.scielo.br/pdf/rbla/v1n1/04.pdf

Birch, J. (1992). Language learning case study approach to second language teacher education. In J. Flowerdew, M. Brock \& S. Hsia (eds.), Perspectives on second language teacher education. Hong Kong, City University of Hong Kong. http://www.sciencedirect.com/science/article/pii/S1877042814015419

Blooth, A., Azman, H., \& Ismail, K. (2014). The role of the L1 as a scaffolding tool in the EFL reading classroom. $\begin{array}{llllll}\text { Procedia - } & \text { Social and Behavioral }\end{array}$ http://portal.cuc.edu.ve/upc/PNFT/INGLES/Principles_of_Language_Learning_and_Teaching.pdf

Brown, H. (2000). Principles of language learning and teaching. Longman: San Francisco. https://books.google.com/books/about/Second_Language_Classrooms.html?id=ZipoGU1sFeYC

Chaudron, C. (1988). Teacher talk in second language classrooms. In M. H. Long, \& J. C. Richards (Eds.), Second language classroom (pp. 50-87). Hawaii: Cambridge University Press. http://www.teslej.org/wordpress/issues/volume5/ej20/ej20r4/

Cole, S. (1998). The use of L1 in communicative English classrooms. LANGUAGE TEACHER-KYOTO-JALT, 22, 11-14. 9780194424752?lang=en\&cc=sa

Cook, G. (2010). Translation in language teaching. Oxford: Oxford University Press.

Cook, V. (2001). Using the first language in the classroom. The Canadian Modern Language Review, 57(3), 402- 423.

Copland, F., \& Neokleous, G. (2010). L1 to teach L2: Complexities and contradictions. ELT Journal, (65), 270-280. http://www.utpjournals.press/doi/abs/10.3138/cmlr.57.3.402

Debreli, E., \& Oyman, N. (2016). Students' preferences on the use of mother tongue in English as a foreign language classrooms: Is it the time to re-examine English-only policies? English Language Teaching, 9(1), 148-162. http://www.ccsenet.org/journal/index.php/elt/article/view/55638

Dörnyei, Z. (2007). Research methods in applied linguistics: quantitative, qualitative and mixed methodologies. Oxford: Oxford University Press.

Dujmović, M. (2014). The ways of using mother tongue in English language teaching. International Journal of $\begin{array}{llll}\text { Language } \quad \text { and } & \text { 2(1), } & \text { 38-43. }\end{array}$ file:///C:/Users/Sir\%20Alex/Downloads/Microsoft_Word_DUJMOVIC_HR.pdf

Ellis, R. (1984). Types of classroom interaction and their role in classroom second language development. Classroom second language development (pp. 83-134). Oxford: Pergamon Press. https://books.google.com/books/about/Classroom_Second_Language_Development.html?id=5hhmAAAAMA AJ

Ellis. R. (2008). The study of second language acquisition (2nd ed.). Oxford: Oxford University Press.

Garcia, O. (2009). Emergent bilinguals and TESOL: What's in a name? TESOL Quarterly, 43(2), 322-326. https://www.jstor.org/stable/27785009?seq=1\#page_scan_tab_contents

Halliwell, S., \& Jones, B. (1991). On target: teaching in the target language. London: Centre for Information on Language Teaching and Research. http://www.journals.aiac.org.au/index.php/IJALEL/article/view/916 


\section{International Journal of Research in English Education}

Hashemi, S. A., \& Khalili Sabet, M. (2013). The Iranian EFL students' and teachers' perception of using Persian in general English classes. International Journal of Applied Linguistics and English Literature, 2(2), 142-152. http://www.journals.aiac.org.au/index.php/IJALEL/article/view/916

Jadallah, M., \& Hasan, F. (2011). A review of some new trends in using L1 in the EFL classroom. https://pdfs.semanticscholar.org/0c53/b4e4b805928868ca5199983b444d3e655fb2.pdf

Jingxia, L. (2010). Teachers' code-switching to the L1 in EFL classroom. Open Applied Linguistics Journal, 3, 1023. https://benthamopen.com/contents/pdf/TOALJ/TOALJ-3-10.pdf

Kavaliauskienë, G., \& Kaminskienë, L. (2007). The effect of individual differences on learners' translation beliefs in EFL $\quad$ learning. $\quad$ Kalbotyra, $132-139$. http://www.academypublication.com/issues/past/jltr/vol04/03/21.pdf

Kharma, N. N., \& Hajjaj, A. H. (1989). Use of the mother tongue in the ESL classroom. International Review of Applied Linguistics, 27(3), 223-235. http://onlinelibrary.wiley.com/doi/10.2307/3588282/full\#references

Krashen, S. D., Terrell, T. D., Ehrman. M. E., \& Herzog, M. (1984). A theoretical basis for teaching the receptive skills. Foreign Language Annals, 17, 261- 275. http://onlinelibrary.wiley.com/doi/10.1111/j.19449720.1984.tb03226.x/abstract

Kumaravadivelu, B. (2006). Understanding language teaching: From method to post-method. New Jersey: Erlbaum.

Larbah, M., \& Oliver, R. (2015). Code switching in ESL classrooms: A study of adult Arabic learners. English Australia Journal, 31, 1, 3-18. https://www.diva-portal.org/smash/get/diva2:691914/FULLTEXT02.pdf

Larsen-freeman, D. (2000). Techniques and principles in language teaching. New York: Oxford University Press.

Levine, G. S. (2003). Student and instructor beliefs about target language use, first language use, and anxiety: Report of a questionnaire study. Modern Language Journal, 87(3), 343-364.

Liao, P. S. (2006). EFL learners' beliefs about strategy use of translation in English learning. RELCJ, 37(2), 191-215. http://journals.sagepub.com/doi/abs/10.1177/0033688206067428

Macaro, E. (1997). Target language, collaborative learning and autonomy. Clevedon, UK: Multilingual Matters.

Macdonald, D. (1993). Learners and modified/negotiated interactions: what works for pronunciation. Language Learning, $\quad 32, \quad 201-227 . \quad$ http://ac.els-cdn.com/S1877042811028758/1-s2.0-S1877042811028758main.pdf?_tid=2a679242-3a08-11e7-8860-

00000aab0f27\&acdnat=1494919420_789ad23ad8f4bbda6451436547d9b220

Machaal, B. (2012). The use of Arabic in English classes: A teaching support or a learning hindrance? Arab World

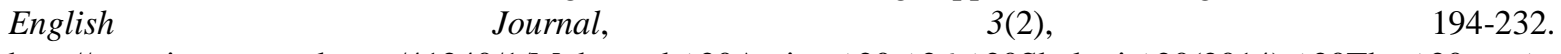
http://repository.um.edu.my/41240/1/Mohamad\%20Azrien\%20\%26\%20Shukeri\%20(2014)\%20The\%20use\% 20of\%20L1.pdf

Mahmoudi, L., \& Amirkhiz, S. Y. Y. (2011). The use of Persian in the EFL classroom--The case of English teaching and learning at pre-university level in Iran. English Language Teaching, 4, 1, 135-140. http://www.ccsenet.org/journal/index.php/elt/article/view/9674

Miles, R. (2004). Evaluating the use of L1 in the English language classroom. School of Humanities. Centre for English Language Studies Department of English. University of Birmingham.

Morahan, M. (2010). The use of students' first language (L1) in the second language (L2) classroom. Retrieved July 20.

Mugla, E. Ü., \& Seedhouse, P. (2005). Why that, in that language, right now? Code switching and pedagogical focus. IJAL, 15(3), 302-325. http://journals.sagepub.com/doi/abs/10.1177/0033688214534796

Nadzrah A. B., \& Kemboja, I. (2009). Using blogs to encourage ESL students to write constructively in English. AJTLHE: ASEAN Journal of Teaching and Learning in Higher Education, 1(1), 45-57. http://journalarticle.ukm.my/1481/ 


\section{International Journal of Research in English Education}

Nation, P. (2003). The role of the first language in foreign language learning. Asian EFL Journal, 5(2). Retrieved September 10, 2007 from: http://www.asian-efl-journal.com/june_2003_PN.php.

Nazary, M. (2008). The role of L1 in L2 acquisition: Attitudes of Iranian university students. Novitas Royal, 2(2), 138- 153. http://www.novitasroyal.org/nazary.pdf

Pennycook, A. (1994). The cultural politics of English as an international language. Longman: London \& New York. Phillipson, R. (1992). Linguistic imperialism. Oxford University Press: Oxford.

Polio, C. (1994). Comments on Elsa Roberts Auerbach's reexamining English only in the ESL classroom. TESOL Quarterly, 28(1), 153-161. http://onlinelibrary.wiley.com/doi/10.2307/3587203/full

Prodromou, L. (2002). The role of the mother tongue in the classroom. IATEFL, 6-8.

Rabani, M. E., Bejarzehi, A., \& Ehsanjou, M. (2014). Iranian EFL high school teachers' attitudes towards the use of L1 in teaching reading comprehension text. International Journal of Language Learning and Applied Linguistics World (IJLLALW), 5(4), 267-276.

Richards, J. C., \& Rodgers, T. S. (2003). Approaches and methods in language teaching (2nd ed). Cambridge: Cambridge University Press.

Schweers, C. W. J. (1999). Using 11 in 12 classroom. The English Teaching Forum, 37(2). Available: http://exchanges.state.gov.forum/vols/vol37/no2/p6.htm (December 12, 2006).

Shahivand, Z., \& Pazhakh, A. (2012). The effects of test facets on the construct validity of the tests in Iranian EFL students. Higher Education of Social Science, 2(1), 16-20. file://C:/Users/Sir\%20Alex/Downloads/2234-28251-PB.pdf

Storch, N., \& Aldosari, A. (2010). Learners' use of first language (Arabic) in pair work in an EFL class. Language Teaching Research, 14(4), 355-375. http://journals.sagepub.com/doi/abs/10.1177/1362168810375362

Storch, N., \& Wigglesworth, G. (2003). Is there a role for the use of the L1 in an L2 setting? TESOL Quarterly, 37(4), 760-769. https://minerva-access.unimelb.edu.au/handle/11343/25294

Swain, M., \& Lapkin, S. (2000). Task-based second language learning: The uses of the first language. Language Teaching Research, 4(3), 251-274. http://journals.sagepub.com/doi/abs/10.1177/136216880000400304

Tang, J. (2002). Using L1 in the English classroom. English Teaching Forum, 36-43. https://americanenglish.state.gov/files/ae/resource_files/02-40-1-h.pdf

Wells, G. (1999). Using L1 to master L2: A response to Anton and DiCamilla's socio-cognitive functions of L1 collaborative interaction in the L2 classroom. The Modern Language Journal, 83(2), 248-254. http://jtls.shirazu.ac.ir/article_1140_59.html

Weschler, R. (1997). Uses of Japanese (L1) in the English classroom: Introducing the functional- translation method. The Internet TESL Journal, III/11. http://iteslj.org/Articles/Weschler-UsingL1.html

Wong-Fillmore, L. (1985). When does teacher talk work as input? In S. M. Gass \& C. M. Madden (Eds.), Input in second language acquisition (pp. 17-50). MA: Newbury House. http://www.ijllalw.org/finalversion8425.pdf

Yaghubi, B., \& Pouromid, S. (2008). First language use in English language institutes: Are teachers free to alternate between L1 and L2 as means of instruction? The Journal of Teaching Language Skills, 4(4), 127-152. http://jtls.shirazu.ac.ir/article_1140_5d4a216f3e9125f538d62d0b25a0c8c4.pdf

Zhou, J. (2003). New wine in an old bottle: Innovative EFL classrooms in China. IATEFL Issues. First published in Issue 172, Apr/May 2003.

Zohrabi, M., Yaghoubi-Notash, M., \& Khodadadi, A. (2014). The facilitating role of Iranian learners' first language in learning English vocabulary. International Journal on Studies in English Language and Literature, 2(8), 4457. http://citeseerx.ist.psu.edu/viewdoc/download?doi=10.1.1.682.8406\&rep=rep1\&type=pdf 